\title{
Using Green Fluorescent Protein to Correlate Temperature and Fluorescence Intensity into Bacterial Systems
}

\author{
K. BELTRÁN, J. M. DE JESÚS-MIRANDA, J. A. CASTRO, \\ L. A. MANDUJANO-ROSAS, J. M. PAULIN-FUENTES, \\ D. OSORIO-GONZÁLEZ*
}

Laboratorio de Biofísica Molecular. Facultad de Ciencias de la Universidad Autónoma del Estado de México. Instituto Literario 100, Col. Centro Toluca, Estado de México C.P. 50000. México.

"Email: dog@uaemex.mx

Published online: August 08, 2016,

The Author(s) 2016. This article is published with open access at www.chitkara.edu.in/publications

Abstract The unique and stunning spectroscopic properties of Green Fluorescent Protein (GFP) from the jellyfish Aequorea victoria, not to mention of its remarkable structural stability, have made it one of the most widely studied and used molecular tool in medicine, biochemistry, and cell biology. Its high fluorescent quantum yield is due to its chromophore, structure responsible of emitting green visible light when excited at $395 \mathrm{~nm}$. Although it is noteworthy that there is enormous available information of the wonderful luminescent properties of GFP, the fact is that there are features and properties unexplored yet, particulary about its capabilities as molecular reporter in several biological processes. In this work, we used recombinant DNA technology to express the protein in bacteria; prepared the bacterial system both in liquid and solid media, and assembled an experimental set to expose those media to a laser beam; thereby we excited the protein chromophore and used emission spectroscopy in order to observe variations in fluorescence when the bacterial system is exposed to different temperatures.

Keywords: green fluorescent protein; bacterial systems; bacterial temperature; spectroscopic properties

\section{INTRODUCTION}

The green fluorescent protein (GFP) is widely known in science and technology, providing a useful tool that spans through all branches of biological sciences

Journal of Nuclear

Physics, Material Sciences, Radiation and Applications Vol-4, No-1, August 2016 pp. $49-57$ 
Beltrán, K de Jesús-Miranda, JM Castro, JA

Mandujano-Rosas, LA Paulin-Fuentes, JM

Osorio-González, D and many other fields. The encoding gene for wild-type GFP (wtGFP) was first cloned and expressed from the jellyfish Aequorea victoria [7], whose study enabled the characterization of the proteins responsible for the bioluminescence. Although this characteristic can be found in a great variety of sea organisms, the wtGFP from $A v$ possess singular features such as stability and the fact that its chromophore is formed by autocatalytic cyclization compelling only oxygen for its maturation and fluorescence, which has an emission peak at $509 \mathrm{~nm}$ in the visible spectrum [5]. Its tertiary structure is a great design of nature because it executes complex chemical processes in ultrashort times; it is composed of 11 antiparallel beta strands, and inside this beta structure there is an alpha helix in the structure center, which encloses the chromophore as shown in Fig. 1.

Such characteristics represent great advantages, especially in molecular biology, where it can be used as a marker for proteins of interest since the structure and function of the involved proteins remain normal [9], which has empowered the study of biological processes with real time resolution.

The fact that GFP is not an enzyme highlights the possibility of its use in species that serve as environmental pollution biomonitors since Fluorescent Proteins (FPs) do not modify at any level the physiological mechanisms of the cell [8].

Moreover, one of the most common uses of GFP is as biological marker, which is classified as a passive application, considering that only reflects expression

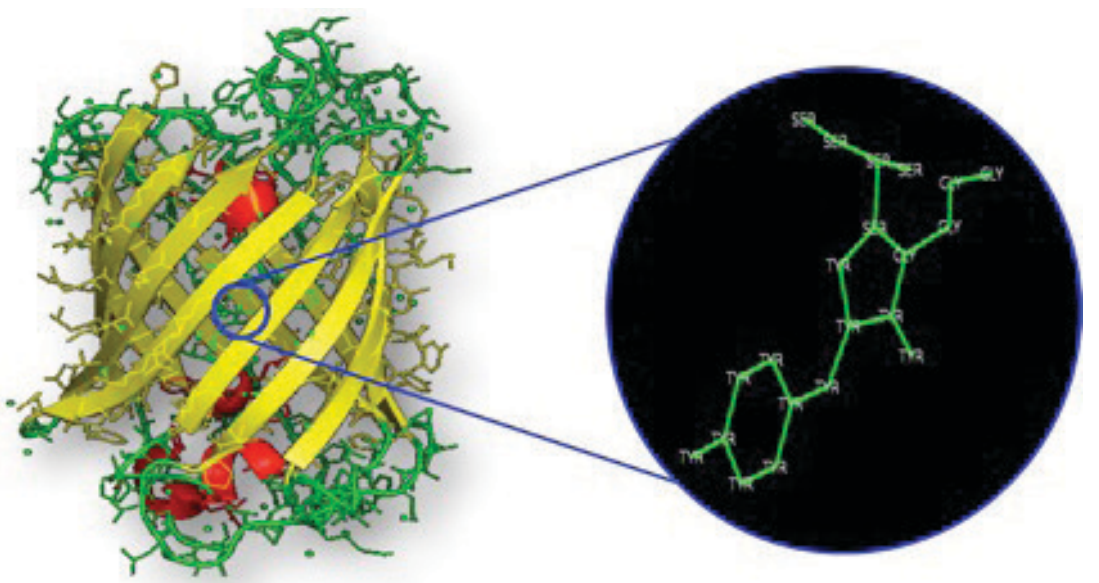

Figure 1: GFP tertiary structure. It is composed of an alpha helix (red) in the structure center with the chromophore (circle) and 11 antiparallel beta strands (yellow) surrounding it. Residues 65-67 (Ser-Tyr-Gly) in the GFP sequence are the fluorescent chromophore. 
levels and subcellular localization of a protein of interest. In contrast, if FPs are bounded to other proteins where fluorescence depends on the environmental conditions, the creation of sensors capable to monitor more complex intracellular processes is more likely to develop in order to obtain values such as activity and cascade signaling display, $\mathrm{pH}$ changes, calcium and potassium levels, voltage, second messenger dynamics, enzymatic activation, protein-protein interactions and conformational changes, which are classified as active indicators [8].

Within the most important applications up to date, is the development of non-invasive techniques using FPs as thermal nanoprobes pretending the gathering of accurate data related to the monitoring of intracellular temperature changes in individual cells in real time, such temperature is obtained through the monitoring of the fluorescence polarization anisotropy [4]. Due to the important role of heating in cell processes like metabolism, cell division and gene expression, to name but a few, this technique results promising since the accurate monitoring of single cells could lead to the control of the aforementioned processes and thus favoring not only its clarification in a complex level, but also the advent of new applications in biology and medicine. For such purposes, a variety of techniques like fluorescence spectroscopy have been created simultaneously with FPs, providing the necessary tools for science in order to perform probes at a molecular level in living cells [2]. Accordingly, the last few years have been dedicated to the constant development of techniques that allow the use of light to reveal structures even smaller than those previously referred in the literature as the bottom limit [1]. Said this, the evolution of both FPs and fluorescence spectroscopy has been made imminent, triggering the study of in vivo processes like never seen before in biology and biophysics, collecting information about kinetic parameters responsible for the affluence and distribution of proteins in cells and tissues [6]. There are many articles that contemplate the aforementioned techniques in their studies, which trend currently leads towards the optimization of FPs with higher excitation wavelengths [2], distinct life times and photo switchable proteins that change colors or photoactivable proteins that change emission intensity following a single light irradiation pulse.

\section{METHODS}

\subsection{Expression and purification of GFP}

GFP was expressed in competent Escherichia coli cells, HB101 K-12 strain, with pGLO plasmid as follows: Individual E. coli colonies grown in solid LB
Using Green

Fluorescent Protein

to Correlate

Temperature and

Fluorescence

Intensity into

Bacterial Systems 
Beltrán, K de Jesús-Miranda, JM Castro, JA

Mandujano-Rosas, LA Paulin-Fuentes, JM

Osorio-González, D

medium $(4 \%)$ were transformed with $10 \mu \mathrm{L}$ of pGLO plasmid $(0.08 \mu \mathrm{g} / \mathrm{mL})$ in $250 \mu \mathrm{L}$ of transformation solution $\left(50 \mathrm{mM} \mathrm{CaCl}_{2}, \mathrm{pH} 6.1\right)$ and $250 \mu \mathrm{L}$ of liquid LB medium (4\%). An osmotic and temperature shock was performed to obtain recombinant cells; cells were incubated on ice for $10 \mathrm{~min}$ followed by $50 \mathrm{~s}$ at $42^{\circ} \mathrm{C}$ and incubated again on ice for $2 \mathrm{~min}$. Hereafter cells were cultured in selective solid LB medium (4\%) supplemented with ampicillin $(0.1$ $\mathrm{g} / \mathrm{L})$ and L-arabinose $(5 \mathrm{~g} / \mathrm{L})$ at $37^{\circ} \mathrm{C}$ for $24 \mathrm{~h}$. GFP expression was verified using a $395 \mathrm{~nm}$ wavelength UV lamp. Individual recombinant $E$. coli colonies were incubated in tubes with $2 \mathrm{~mL}$ of $\mathrm{LB} / \mathrm{amp} /$ ara broth (4\% LB, ampicillin $(0.1 \mathrm{~g} / \mathrm{L})$ and L-arabinose $(2 \mathrm{~g} / \mathrm{L}))$ on an orbital shaker at $32{ }^{\circ} \mathrm{C}$ for $24 \mathrm{~h}$ and $200 \mathrm{rpm}$. After protein expression, cells were harvested by centrifugation at 20 ${ }^{\circ} \mathrm{C}$ for $5 \mathrm{~min}$ and $14800 \mathrm{rpm}$, and resuspended in $250 \mu \mathrm{L}$ of Tris-EDTA buffer (TE; $10 \mathrm{mM}$ Tris, $1 \mathrm{mM}$ EDTA, pH 8.0). The cells were lysed by incubation with lysozyme followed by freezing for $24 \mathrm{~h}$. Cells were thawed in hot water and then centrifuged at $20^{\circ} \mathrm{C}$ for $10 \mathrm{~min}$ and $14800 \mathrm{rpm}$; the supernatant was used for protein purification with Macro-Prep® .

GFP was purified at room temperature on columns of hydrophobic interaction chromatography $(8 \times 40 \mathrm{~mm})$ pre-packed with methyl resins and pre-equilibrated with $2 \mathrm{ml}$ of equilibrium buffer $\left(2 \mathrm{M}\left(\mathrm{NH}_{4}\right)_{2} \mathrm{SO}_{4} / \mathrm{TE}, \mathrm{pH}\right.$ 8.0). $250 \mu \mathrm{L}$ of binding buffer $\left(4 \mathrm{M}\left(\mathrm{NH}_{4}\right)_{2} \mathrm{SO}_{4} / \mathrm{TE}, \mathrm{pH} 8.0\right)$ and $250 \mu \mathrm{L}$ of wash buffer (1.3 M $\left.\left(\mathrm{NH}_{4}\right)_{2} \mathrm{SO}_{4} / \mathrm{TE}, \mathrm{pH} 8.0\right)$ were used for each $250 \mu \mathrm{L}$ of supernatant followed by $750 \mu \mathrm{L}$ of TE as elution buffer. All reagents were obtained from BioRad.

\subsection{Evaluation of temperature and fluorescence}

The experimental samples consisted of bacterial colonies expressing GFP in solid LB medium, including ampicillin as a selectable marker and arabinose as an inducer. For this system, two control samples were used; the former was equivalent to the experimental, except for arabinose, so the bacterial colonies did not express the protein; the second consisted only of solid medium, without bacterial growth. Similarly, for the liquid medium system, the first control sample consisted in liquid medium without arabinose, so that the bacteria remained without expressing the protein, and the second control consisted exclusively of liquid medium.

We used the radiation of a $405 \mathrm{~nm}$ CW laser (Fermion I Series, coupled to an optical fiber) with an average output power of $100 \mathrm{~mW}$ to excite each sample. By using a laser beam expander we increased the size of the circular laser beam up to $2 \mathrm{~cm}$ in diameter to optimize the laser power density at the focal point. This beam expander was adjusted with micrometric displacement 
to correct the divergence of the laser beam. The incident beam wave was directed toward a $\varphi=2.54 \mathrm{~cm}$ diameter, $\mathrm{f}=10 \mathrm{~cm}$ effective focal length planoconvex lens; the beam was subsequently directed to the samples and controls placed in a $1 \mathrm{~cm}$ path length quartz cuvette filled to $1 \mathrm{ml}$. The focus of the beam is made so that the beam waist hits the center of the sample, as it is shown in Fig. 2.

The temperature variation of the transformed bacterial system was measured by implementing a quartz cuvette with a capacitive sensor (LM35 temperature sensor) immersed in the medium (by isolating the sensor wires with an epoxy resin). Such sensor was connected to a sensor microcontroller and data acquisition board (Arduino Board Yun) with open-source hardware (OSH), free and open-source software (FOSS), and USB communication. The intensity of both the laser source and the fluorescence emissions of the samples, were measured with a spectrometer (USB4000-UV-VIS Ocean Optics), by scanning from 200 to $1100 \mathrm{~nm}$. The end of the optical fiber coupled to the

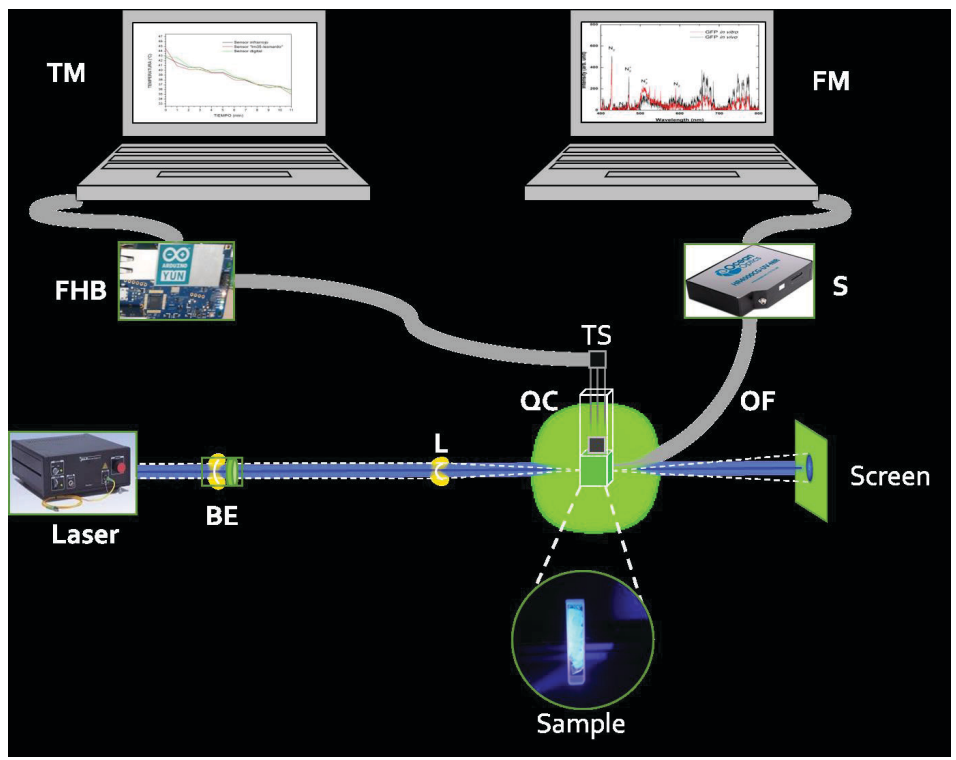

Figure 2: Experimental setup. The samples were placed in a quartz cuvette that was enabled for measuring temperature. The GFP expressed in bacteria was excited by a violet $405 \mathrm{~nm}$ laser, and the fluorescence emission was monitored with a high resolution spectrometer. (BE) Beam expander, (FHB) Free Hardware Board, (FM) Fluorescence monitor, (L) Lens, (OF) Optical fiber, (QC) Quartz cuvette, (S) Spectrometer, (TM) Temperature monitor, (TS) Temperature sensor.
Using Green Fluorescent Protein

to Correlate

Temperature and

Fluorescence

Intensity into

Bacterial Systems 
Beltrán, K de Jesús-Miranda, JM Castro, JA

Mandujano-Rosas, LA Paulin-Fuentes, JM

Osorio-González, D spectrometer was placed $1 \mathrm{~mm}$ away from the wall of the quartz cuvette and perpendicular to the laser axis.

Both the free hardware board and the spectrometer were connected to a PC for experimental data acquisition and manipulation. To achieve a desired temperature, the samples were placed in incubation and cooling to keep them in a range between $4^{\circ} \mathrm{C}$ and $37^{\circ} \mathrm{C}$. Verification of the surface temperatures were carried out with an infrared thermometer.

\section{RESULTS AND DISCUSSION}

One ml of purified GFP in TE solution at different concentrations was submitted to laser irradiation with temperature variations between $10^{\circ} \mathrm{C}$ and $25^{\circ} \mathrm{C}$; the corresponding emission spectrum was determined, and is shown in Fig. 3. In order to fit such spectrum, we used Lorentz functions to lately corroborate that the maximum emission peak is located at $510 \mathrm{~nm}$ with a bump at $540 \mathrm{~nm}$, as reported in the literature [3].

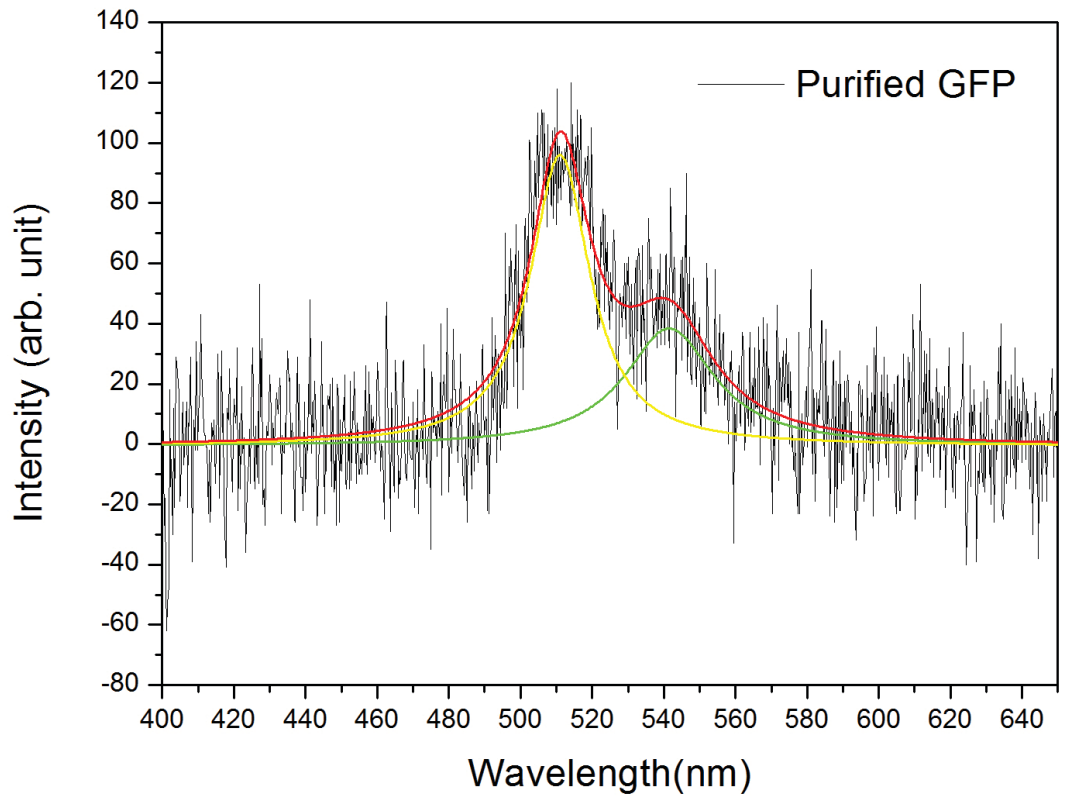

Figure 3: Emission spectrum of purified GFP. The adjusted curves show a maximum emission peak at 509nm (yellow) and a bump at $540 \mathrm{~nm}$ (green). The resulting curve (red) is the overlap of both Lorentzian curves. 
The fluorescence spectrum of proteins depends on both the amino acid composition and the conformational state. Previous studies show that fluorescence intensity depends on factors such as $\mathrm{pH}$, the amount of dilute oxygen in the medium and the number of transformed bacteria [10]; however, for a system with equal physicochemical conditions is important to acknowledge the fluorescence variation in function of temperature as it is a factor that enables the monitoring of unfolding processes in proteins.

Samples with transformed bacteria in solid medium were prepared and incubated at $37^{\circ} \mathrm{C}$ whilst others were kept refrigerated at $4^{\circ} \mathrm{C}$ for $12 \mathrm{~h}$. The fluorescence was verified until samples reached room temperature $\left(22^{\circ} \mathrm{C}\right)$; no significant difference was found in the registered spectra for both samples. Moreover, bacteria in liquid media samples were prepared under same conditions above mentioned, and the emission spectrum displayed a decrease in the fluorescence intensity as the temperature was increased. This difference became more evident in the range of temperature between $15^{\circ} \mathrm{C}$ and $25^{\circ} \mathrm{C}$. The fitted curves to the spectra are shown in Fig. 4.

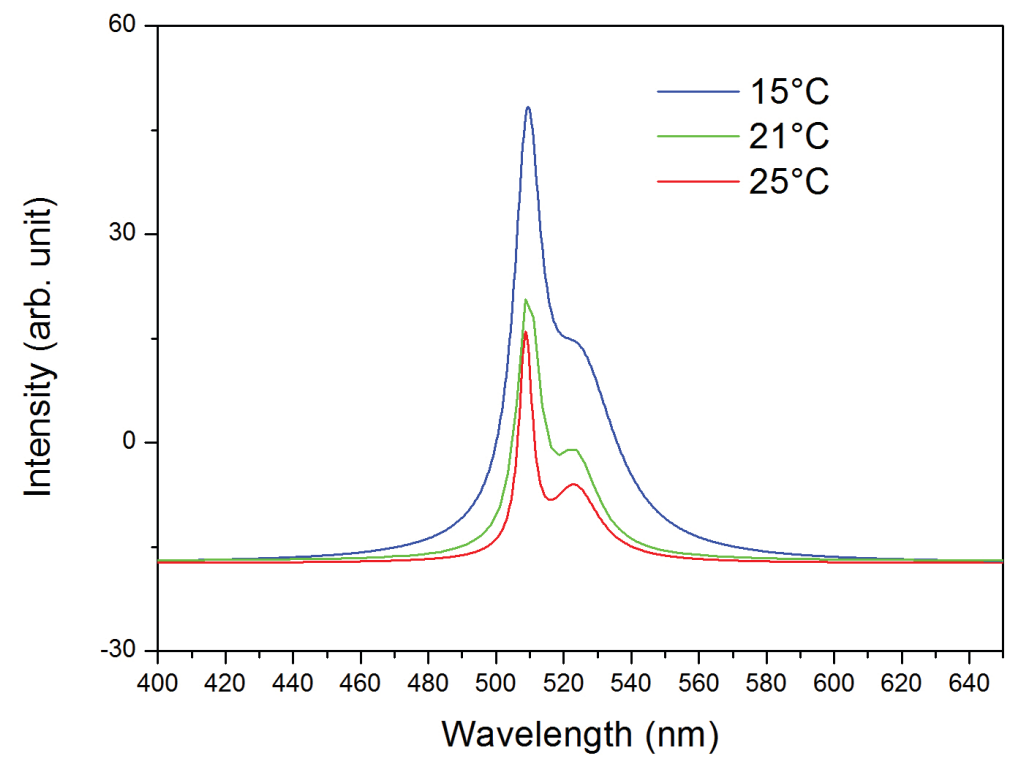

Figure 4: Fitting of the emission spectra of GFP expressed in bacteria in liquid medium, where a decrease in fluorescence as the temperature increases can be noted. 
Beltrán, K de Jesús-Miranda, JM Castro, JA

Mandujano-Rosas, LA Paulin-Fuentes, JM

Osorio-González, D

\section{CONCLUSIONS}

GFP is one of the most important and widely accepted molecular markers of biological processes, so it is particularly important to analyze its thermal stability and behavior in bacterial systems as it allows to establish conditions under which such protein can play reliably its role as molecular reporter. The outcomes found in this experiment enabled the analysis of the fluorescence changes in the GFP expressed in bacteria when temperature was increased from $15^{\circ} \mathrm{C}$ to $25^{\circ} \mathrm{C}$, showing that the energy-structure relation between the three amino acids that shape the chromophore and the rest of the protein is more stable in solid medium than in liquid medium. In the latter medium, fluorescence decreases as temperature increases; we assume this phenomenon is explained in terms of the chromophore thermo-sensitivity at this temperature range, and presumably is due to the partial increment of the fluctuations in some of its regions. This is a significant fact for the function of GFP as a molecular reporter, since its fusion with other proteins converts its fluorescence in a quantifiable parameter in order to study the folding, and even the enzymatic activity, of thermophile proteins in bioprocesses where temperature changes are imminent.

\section{ACKNOWLEDGEMENTS}

The authors would like to thank Autonomous University of State of Mexico for supporting this research through project ID 3697/2014/CID, and Dr. Lorena Romero-Salazar from Nanothermodynamics and Complex Systems Laboratory for providing us with facilities for the timely development of the project.

Authors K B and J M P wish to thank Mexican Council for Science and Research (CONACyT) for the individual research grants received.

\section{REFERENCES}

[1] Baker, M. Microscopy: Bright light, better labels. Technology feature. Nature. 478: 137-142. (2011). http://dx.doi.org/10.1038/478137a

[2] Blow, N. Cell imaging: New ways to see a smaller world. Nature. 456: 825-828. (2008). http://dx.doi.org/10.1038/456825a

[3] Chalfie, M., Tu, Y., Euskirchen, G., Ward, W. W. \& Prasher, D. C. Green Fluorescent Protein as a Marker for Gene Expression. Science. 263(5148): 802-805. (1994). http://dx.doi.org/10.1126/science.8303295

[4] Donner, J., Thompson, S., Kreuzer, M., Baffou, G. \& Quidant, R. Mapping intracellular temper-ature using green fluorescent protein. Nano Letters. 12(4): 2107-2111. (2012). http://dx.doi.org/10.1021/nl300389y 
[5] Hernández, C.M. Caracterización funcional y ensamblaje membranal del canal de potasio shaker $\mathrm{H} 4$, y de segmentos truncados en la porción amino o carboxilo. Tesis de maestría. Un-iversidad de Colima, (2001).

[6] Knop, M. \& Edgar, B. A. Tracking protein turnover and degradation by microscopy: photo-switchable versus time-enconded fluorescent proteins. Open biology, (2014). doi:10.1098/rsob.140002 http://dx.doi.org/10.1098/rsob.140002

[7] Prasher, D. C., Eckenrode, V. K., Ward, W. W., Pendergast, F. G. \& Cormier, M. J. Primary structure of the Aequorea victoria green-fluorescent protein. Gene 111(2): 229-233. (1992). http://dx.doi.org/10.1016/0378-1119(92)90691-H

[8] Tsien, R. Y. The green fluorescent protein. Annu Rev. Biochem. 67: 509-544. (1998). http://dx.doi.org/10.1146/annurev.biochem.67.1.509

[9] Wang, S. \& Hazelrigg, T. Implications for bed mRNA localization from spatial distribution of exu protein in Drosophila oogenesis. Nature. 369(6479): 400-403. (1994). http://dx.doi.org/10.1038/369400a0

[10] Zhang C, Liu M. S. \& Xing X. H. Temperature Influence on Fluorescence Intensity and En-zyme Activity of the Fusion Protein of GFP and Hyperthermophilic Xylanase. Appl. Microbiol. Biotechnol. 84(3): 511-517. (2009).

http://dx.doi.org/10.1007/s00253-009-2006-8
Using Green

Fluorescent Protein

to Correlate

Temperature and

Fluorescence

Intensity into

Bacterial Systems 